\title{
Q
}

\section{Phyto-Performance and the Lost Gardens of Riga}

\author{
Alan Read
}

The 'English Garden Effect'- a phrase borrowed from the poetry of John Ashbery, first written by the novelist Walter Abish in his short story of that name-describes a process by which a landscape might be rearranged to conceal its historical determinants by those who might gain from such scenic concealing. In his story Abish writes, 'Remnants of the old atrocity persist, but they are converted into ingenious shifts of scenery, a sort of "English Garden" effect to give the required air of naturalness, pathos and hope'. ${ }^{1}$ I am interested in what such an 'English Garden Effect' might mean for us as artists, outsiders, visitors, to my proposed phyto-place of performance-looking for a way to work that eschews the opportunistic occupational mode of the site specific, and thinks itself into site in a more responsive and responsible fashion.

Phyto-Performance, that is, not just theatres representing vegetal matters - of which The Little Shop of Horrors (1960) might be taken as an early baroque example-but practices of co-presentation alongside and within plant processes, could be expected to offer affective insights to the deep ecology of these rearrangements. Such performances (in the spirit of the

\footnotetext{
A. Read $(\bowtie)$

King's College London, London, UK

e-mail: alan.read@kcl.ac.uk

(C) The Author(s) 2019

P. Hildebrandt et al. (eds.), Performing Citizenship, Performance

Philosophy, https://doi.org/10.1007/978-3-319-97502-3_15
} 
plant philosopher Michael Marder) would undermine casual correlations between the vegetal, the whimsical, and the romantic, and might reacquaint us with the robust materiality of flora, the dark side of roots, the infra-thin movement of leaves. The repertoire of such practices, however, has been drastically limited within contemporary performance by a humanist theatre that places homo sapiens and their limb-heavy exertions centre stage.

Phyto interests, from the Greek word for 'things that grow', have most recently been championed in all their unpredictability by the philosopher Michael Marder, in his ground-breaking book Plant-Thinking. ${ }^{2}$ Phytothought, you could call it, has been common to the literary and philosophical imagination, vigorously spreading its tendrils since Plato. It is now relevant to the philosophy of a number of thinkers whose broad interest is in vegetal life, a decentralizing of the human from plant perspectives, among whom the French philosophers Gilles Deleuze and Felix Guattari's work on the rhizome would be the most obvious example. ${ }^{3}$ But that casually metaphoric use, and some might say philosophical and interpretive abuse of plants, is not where I intend to take us in this short essay.

First, by way of a brief biographical sketch to establish the somewhat fanciful link between the vegetal and citizenship here, I would like to recover something more material from Guattari's work-to remind us of the relationship between the questions I am posing on performance and 'troubled citizenship' that I think the vegetal invites. These ideas began to germinate for me in 1992, and were prompted in person by Guattari, who had come to London (just before he prematurely died of a heart attack in 1994), to discuss his newly published essay The Three Ecologies.

On finally shoe-horning a considerable audience into the modest Institute of Contemporary Arts theatre space on The Mall ( $A$ Thousand Plateaus, in the translation by Brian Massumi, had been doing great business at the ICA bookshop for years), I recall him insisting, before he could possibly speak to the assembled expectant group, that this kind of arrangement just would not suffice for the democratic purposes of his work. When the co-author of Mille Plateaux says he does not like the seating set up, you take note.

I am committed to the idea that one's ends and means should be linked formally (whether that be the way we conduct ourselves academically or otherwise, in all settings, whether they be conference arrangements or the street protests these intellectual assemblies often articulate), and so I readily agreed that we should remove the tiered bench seating, designed to ensure everyone could see, and seat everyone on the floor in a circle 
around Félix, who promptly positioned himself sitting at their centre, therefore, by definition, with his back to a proportion of the audience who had come to listen to him. Félix had a rather soft voice and started with this passage from the work he was with us to discuss, The Three Ecologies:

Now more than ever, nature cannot be separated from culture; in order to comprehend the interactions between eco systems, the mechanosphere and the social and individual universes of reference, we must learn to think 'transversally'. Just as monstrous and mutant algae invade the lagoon of Venice, so our television screens are populated, saturated by 'degenerate' images and statements. In the field of social ecology, men like Donald Trump are permitted to proliferate freely, like another species of algae, taking over entire district of New York and Atlantic City; he 'redevelops' by raising rents, thereby driving out tens of thousands of poor families, most of whom are condemned to homelessness, becoming the equivalent of the dead fish of environmental ecology. (Guattari 2000, p. 43)

Well, that was Félix Guattari at the ICA in 1992, prescient at least. Few who were present appeared either to know what he was talking aboutnever really having heard of Donald Trump-nor could they readily get the analogy to algae, as they could not hear what he was saying and his pronunciation of algae was quite baroque. It took a brave heart to suggest at this stage that, given we were all there to listen to Félix, we might want to return to a seating arrangement in which he could be heard-a less formally democratic proposal maybe, but a functional one at least. So we, or I should say, the stage managers and I, set about putting the theatre back into the shape it had been especially put into an hour before, pulling the retractable seating out again, much to the exasperation of the ICA technicians who muttered something about their labour clearly being the one absolutely infinite resource available to intellectuals who require optimum circumstances for their own labour, with little respect for the call these demands place on others tasked with putting out chairs, taking them away, then putting them out again, in pursuit of the ideal democratic arrangement.

Within this disturbance to the shape of a gathering, Guattari's idea of 'transversality' was already underway within that room. There and then, as much in the form of the discussion and disagreement about the seating and ways of resolving that local dispute as it was in his startling theoretical diagnosis, his forensic analysis of the newly empowered rentiers of the 
Reagan and Thatcher years, those beyond any constraint of something once called society-Donald Trump's instinct for gated communities, camps of the $\ddot{u} b e r$ elite that, like algae, would proliferate across the fetid lagoon of the cosmopolitan class. Beyond the remarkable vegetal allegories that I will return to in the balance of this essay, I was aware-as early as the mid-1990s - that another elite, an educated elite circulating through the theoretical groves that I was responsible for organizing there, at the ICA, had little sense of the question posed to them by those who were responsible for moving those chairs around at their will. A question of the disaffection of labour and also a question that Donald Trump himself would notice provided him with an opportunity and an electoral mandate of $52 \%$ some years later. That at that time a certain 'will to power' was manifest within a liberal elite who were beginning to deploy intersectional theory to constitute themselves as polymorphously free of - or at least playful with-multitudinous identity formations, at the same time as forgetting to re-inscribe their analysis with any due regard for that other multitude with less than one identity, long left behind by successive government attacks on education and the welfare state. I think these reflections could be inscribed within frames of citizen and non-citizenship.

I returned to Guattari's material thinking about algae and the politics of oppression when Michael Marder ${ }^{4}$ visited us at King's College London, where I moved a few years after that time at the ICA. There, Marder offered an audacious, panoramic survey of philosophy's entanglements with vegetal thinking. For instance, selecting one hidden herbalist among many, Friedrich Nietzsche-as Marder drew to our attention-dwelt very precisely upon the vegetal in the form of the 'jungle' - or as it has been more recently translated by Kevin Hill in Nietzsche's newly translated notebooks, 'primeval forest'-in his notes on The Will to Power (2017) which were, without his permission and indeed against his expressed view, collected together and published after his death by his sister, Elisabeth Forster-Nietzsche in 1901. But Nietzsche did so only after a detour through the 'arrant misrepresentations' and 'counterfeits' of psychology. In fragment 704 in 'The Will to Power in Nature' (written between November 1887 and March 1888), Nietzsche questioned 'Man's' striving after happiness. To understand anything about life Nietzsche, unusually perhaps for the philosophical tradition, insisted on an expanded sense of life, a 'formula that must apply to trees, and plants and animals'. Nietzsche even takes the trouble to notice the structural problem when asking what 
a plant might strive after, a false unity which does not exist, given the 'fact of million-fold growth'.

Michael Marder has, since that event, where we first heard these ideas, discussed this passage in Nietzsche's work, ${ }^{5}$ fleshing it out, or more appropriately, inter-leafing it with some fascinating material insights borne of his fascination with plant practices. Unbeknownst to themselves, who appear to know little of Nietzsche's view perhaps, Michael Marder suggests that scientists confirm Nietzsche's hypothesis in examining kin recognition of plants. Specimens of the plant Cakile edentula, for instance, produce more roots when they share a pot with strangers (that is, plants of the same species, grown from seeds that derived from a different mother plant) than when they germinated in the same pot as their kin (defined as plants grown from seeds collected from the same mother plant). So, Marder is drawn to suggest that Nietzsche's interpretation of the 'fight' amongst trees in a jungle is also a 'theoretical fiction', which in turn naturalizes the struggle for survival in human societies, rather as the work of Konrad Lorenz had done with supposedly red of tooth and claw animalities of the midtwentieth century, against the conclusive research of Ashley Montagu that reframed atavistic nature as altruistic nature.

Such striving, such 'will', will always occur in the face of something that Nietzsche says 'resists', as he posits: 'For what do the trees in a jungle fight each other? For happiness? - For power! -'. But amongst these competitive columbines there are other million-fold symbiotic forms of species coexistence which with some plant thinking, Marder suggests, some properly environmental thinking of the kind I will offer in this essay, might operate in more sympathetically entangled ways. It is not that 'the jungle' offers another metaphor with which to squeeze the pips of the vegetal, but rather, a material/historical site where kinship relations between plants have been observed; where to strive to 'be in the sun' could be conceived as more than an ontological imperative against entropy, where to persevere in being is itself the genesis of the performative comportment that will always trouble presumptions of citizenship.

In thinking about some of our performance concerns, namely, movement, our awareness of the surrounding world and life itself, Marder reminds us, we do not tend to associate thinking with plants. If we consider them at all, we think of plants 'shrouded in obscurity'-as Marder cites Thomas Aquinas in his introduction to Plant-Thinking. We maybe fail to recognize ourselves in plants. And thus, plants provide us, Marder would suggest possibly unwittingly, with a welcome short-circuit in the 
anthropocentric machinery. That is, the machinery that ceaselessly compares us with other animals and, having found comparisons wanting, coopts other animals in our interests for our instrumental ends. It is, Marder proposes, a good thing that we do not recognize ourselves in plants. It is their foreignness that might trouble us, but it is this 'otherness' that protects us from too easy assimilation of what they intrinsically are-'Not us'. ${ }^{6}$ I would stress here that this writing will have failed if you think what I am promoting is an appetite to cast, to draft in, plants into performance; to squeeze them for their pips, to mimic their movement or to transplant their roots.

But, I would suggest here that a fresh approach to movement, to surroundings and to life itself - in the spirit of Marder's vegetal thinkingmight be recognized in plants if we look and listen carefully enough. Just so we can leave some of our zoological bias at the door, movement itself immediately throws up some problems for thinking phyto-centrically. Our ideal movement, we might have to admit at the outset, is an animal movement; by which I mean we have the capacity for locomotion. The whole rhetoric of human disability with regard to movement is based upon just such a spurious norm. Just think of words like crawling and striding for their comparative place within an unwritten hierarchy of power to measure something of this loco-normativity. In saying this, and celebrating human locomotion over other movements, we forget, that plants move at their edges, their leaves, at their centre, their stem, and indeed, most voraciously, underground. ${ }^{7}$ Growth itself - though in its own time and always patient compared with our pre-emptive leaps and impatient spasms - is a kind of movement.

So, while we might not be able to recognize ourselves in plants, we perhaps should be able to recognize-Marder ingeniously suggests- the vegetal inside us. The 'otherness' of vegetal life within us is a good antidote to anthropomorphism; we should begin here to recognize something of the plant in $u s$, not us in them. And this perhaps is where the affective response to performance might begin to make sense vegetally. Phytocentrism thus halts the anthropocentric urge of humans-for us to situate ourselves as central to a biosphere-which, irrespective of the cultivations of indigenous peoples and the mass-farming of their successors, got on quite well before us. The decentralized nature of plants themselves then, poses some interesting questions for us in performance. By putting plants in the centre, Marder insists-probably in light of a familiar 
questioning of his project-do we not just repeat anthropocentrism and its humanist ills?

Well, not exactly, as they-plants, that is-are not unified organisms. It is difficult to tell where a part of the plant begins and ends, it is difficult to pinpoint identity in vegetal life. The truth of the matter, for Marder at least, is that to place the plant at the centre of our life is to 'decenter the center'-the centre implodes along with the penumbra. ${ }^{8}$ And that might not be such a bad thing when we seek ways of performance that can draw upon the abandonment of plants as a means by which such abandonment itself can become the spur to the recovery of lost techniques, disciplines and practices for plants' better protection. The performance Lost Gardens is an exemplary act in just one such homeopathic register (Fig. 1).

Lost Gardens, in which I was a participant in the 2013 Riga Homo Novus Festival, was directed by Christine Umpfenbach from Munich, who explores social realities in her performance pieces, focusing on migration,

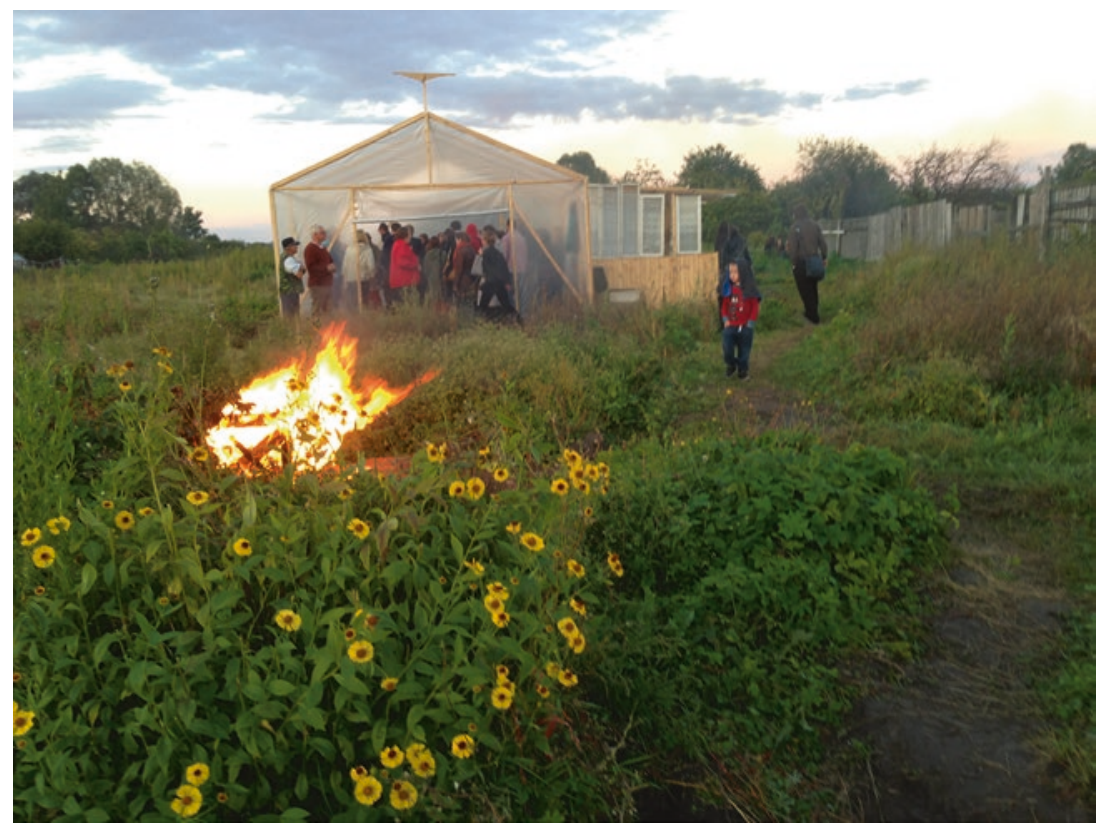

Fig. 1 Lost Gardens, Riga, 2013, Dir. Christine Umpfenbach. (Photo Copyright Homo Novus Festival) 
labour, and the realm of the city. The performers one meets in Lost Gardens, as in other Umpfenbach projects, are mostly non-actors-people engaged in other professions, older people, children. They could be your neighbours. Umpfenbach collaborates on this occasion with Latvian video artist Katrina Neiburga and Austrian artist and scenographer Rudolf Bekic - who had been living in Latvia for a number of years, working with hand-made objects and mechanisms. Zane Zajančkausk, a Latvian editor, curator, producer and a researcher of communities, worked as director's assistant on the Lost Gardens project, researching 'small garden culture' and helping in the project's admirable and complex commitment to extended communication with the local groups and individuals who wished to be involved in the event.

The programme for the event sets out the context like this:

In May 2013, a lane was cut through the allotment gardens in Bolderāja to free up the space for railway tracks as a part of the Riga Free Port development plan. Gardeners lost their gardens, fences were knocked down, trees were cut, garden houses were burned down or were demolished by bulldozers. The traumatic event had a big impact on the lives of these gardeners, who after spending every summer there, now have no place to go. Many of them started 40 years ago as young families to cultivate this area from being a swamp into the place in which trees, fruits and vegetables could grow and flowers would bloom. ${ }^{9}$

The 'English Garden Effect' comes to mind as we group here amidst a landscape of 'rearranged' structures, gardens and fences. It is clear that there has been some 'rebuilding' for the purpose of this event, but not so much as to conceal the shattering experience these carers for the soil have experienced. We gather hesitantly, in loose assemblages of between 10 and 14 folk - a community of those who have nothing in common, while looking on at a community who most definitely do. Loss (Fig. 2).

We are split into separate witnessing alliances rather than anything approaching an 'audience', and gently we are asked to follow one of six leaders. We are given a piece of cut fruit or vegetable-something with a distinctive colour-to mark us out from the other groups, as though we might not remember to whom we belong. And indeed, as we walk together slowly through the gathering twilight gloom of a late summer evening in Riga, there is something to be said for this small token of identity. For as one engages with each 'station' in the landscape-a small shed here, a 


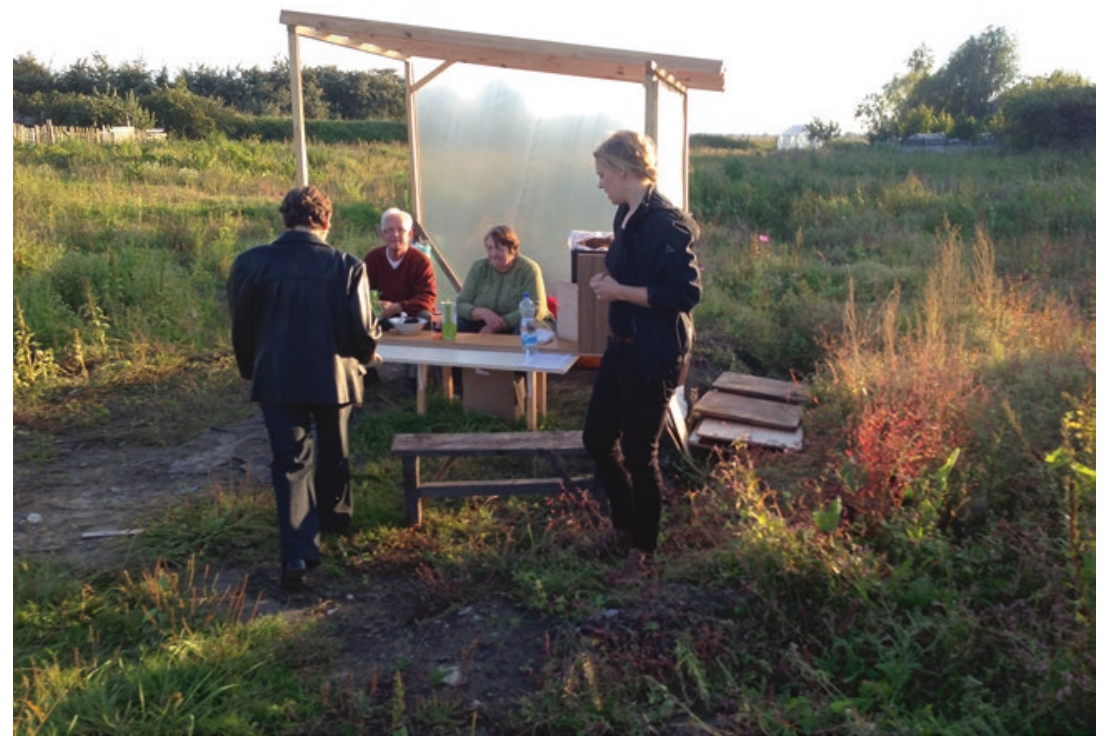

Fig. 2 Lost Gardens conversation station. (Photo Homo Novus Festival)

makeshift stand there, a soup being cooked here, a television playing an episode of some injustice there-the sense of one's own self begins to dissipate and mix with the horticulture that this land was once given over to, before the bulldozers came and made way for the Free Port Authority development that would pour asphalt over 40 years of shared nurturing of this land.

The protagonists in this performance are the displaced gardeners and, peculiarly democratically, a representative from Riga Free Port (who lectures us on the bus en route to the location), who explain their perspectives on what had happened and recall the event through their points of view. This is how two of these participants are described:

Asja bought her garden 30 years ago for her father in order to help keep him busy and give him a purpose in life. After his death, she continued to maintain the garden to help her relax. One day, she returned to the garden to find it had been burned to the ground. She wrote to the Free Port authority 
asking for explanations as to why she was not given notice of the demolition.

Anatolijs and his wife grew fruits and vegetables in their garden so they never had the need to go to the market to buy fresh products. He and his wife stood there watching his fruit trees being cut down. Together with his granddaughter Liza, he explains how his garden house was relocated by a crane to an area 30 meters away from the original location. ${ }^{10}$

Each of the stations one visits as part of the two-hour event is a small bricolage edifice within the landscape, hewn from the materials at hand. Each station is attended to by one of the residents, who in several cases prepare food from the ground nearby and serve a hot bowl of broth or salad and fruits as we perambulate. The pace of each of these hosting gestures - that become the time of the theatre event - is closer to the patience of the slow-grown plants that, in this instance, appear more as co-actors in a network of distributed performances across this threatened landscape.

The evening ends, in as much as it can end, in a tent situated in the landscape, with a glowing fire outside and a supper laid out within, served by those who have been telling their stories of displacement. They stand in simple tableaux in the opening of the tent as we watch on from inside, looking beyond them to the long sunset across the landscape that is now not theirs.

The coaches wait for us in the discrete distance, as though to remind us that this country, this contra, is only what it is because of the other it is not: the city to which we are about to be returned, passing through the advertising lights of the petro-chemical companies and banks that edge Riga's fringe.

If plants remind us of anything, it is of the power to wait-both the ability to wait, and the capacity to let others wait. Peter Sloterdijk suggested that democracy could be said to be based on a proto architectonic ability to build waiting rooms, and perhaps glasshouses are just the antithesis of such things. ${ }^{11}$ Yes, they allow humans to wait for plants, but their controlled environments represent a strategic quickening of natural growth. If Lost Gardens, in its lugubrious pace, wandering dramaturgy and peripatetic pauses showed us anything or invited us to feel something, it was that the time of the landscape and the time of those carers for that landscape-different as they were-contrasted with the time of development. The Riga Port Authority operated to rhythmic imperatives that were just wholly at odds with those who not only had waited four decades 
for trees to grow amongst them, but were now willing to wait for four hours in the twilight as we made circuits around their makeshift stalls, insisting on trying just about everything that was on offer from their addled ground. There were structures in this landscape, yes, but glasshouses and their urgencies were nowhere to be seen, before or after the heavy-duty lifting gear arrived in this miserable-en-scene.

Lost Gardens allows us to consider what Phyto-Performance might look and feel like. There is a commitment here to the cycles of plant growth and retreat. On the one hand, the horticulture of the Rigan allotments sets the pace for the event we wish to enter into, as an audience with its own festival chronotopes to maintain. The programme of the Homo Novus Festival offers so many delights that we could move onto, but the entangled, pedestrian pace of this event seems to demand our attention beyond such accelerated departures elsewhere to see 'yet more culture'.

How much longer might we be free to stay here amongst the infinite smells and senses of the landscape should we have nowhere special to go? Festival time, and its topsy-turvy characteristic that Bakhtin made so much play of in his idea of the Carnivalesque, is here substituted by something altogether more alluring for me: plant time. Here there is no topsy-turvy, no day out from the remorseless ministration of power; indeed, the entire event is conducted under an umbrella of ever-present melancholy, of subjection, of the cruel optimism that comes from being down there with plants and knowing one's place when it comes to capital investment. But, critically, finding the words and recipes of the earth and at that very moment expressing that relationship, might be of some significance to the future of the land. Vegetal matter is setting the pace in this environment as Asja is unable, or unwilling, to turn the flame up under those root vegetables and expect them to hurry along for the sake of theatre. They will take their own time to simmer, and that, for me at least, feels for the better.

Lost Gardens digs a vegetal environment and, in so doing, constructs a site of uncertainty, if it is anything, and therein lies its eloquence. The people doing the speaking here-namely, Asja, Zeta, Kosta, and Ninaare, in their doing, marking their own infidelity to what lies in those propagation beds, doing what they so beautifully but fantastically suggested the plant-ish humans might be doing in such warm-damp places. Here, that labour of oratory on behalf of plants and humans is a properly performative process; it is a Phyto-Performance that, in the playing out, recognizes and measures the degree to which it falls short of its subjects. 
Phyto-Performance has no need to translate its matters of concern into matters of fact. That is the stuff of science. It is the 'English Garden Effect' that rearranges these 'old atrocities' into 'ingenious shifts of scenery $[\ldots]$ to give the required air of naturalness, pathos and hope'. ${ }^{12}$ PhytoPerformance has always, already, been the ground of the English theatre, as well as its canopy in the plant-adorned proscenium arch. When actors take their leave from responsibility to their character-lives on stage, they do so to a place called the Green Room. Adjacent to the stage, to the side of the wings, in all English theatres from the late eighteenth century on, the Green Room has this designation for ecologically informed reasons. It was the home of the 'green thread' of the stage and provided shelter to the theatre's environmental credentials and vegetal potential. The Green Room was so called because it housed the Greensward, the carpet that would be rolled out from the wings, across the width of the stage, to mark the forthcoming scene as one set outdoors, external, a grassy one; one that was inclusive to the possibility of plant-as distinct to drawing roommatters. The Green Room has long since lost its grass, occupied as it is by those actors who do not know why 'the old atrocities still persist', while audiences look on, in the dark, in serried arrangements of naturalness, pathos and hope.

\section{Notes}

1. Abish, Walter (1980) 'The English Garden Effect' in In The Future Perfect, p. 1 .

2. Marder, Michael (2013) Plant-Thinking: A Philosophy of Vegetal Life.

3. See Gilles Deleuze and Felix Guattari (2004) A Thousand Plateaus: Capitalism and Schizophrenia.

4. Michael Marder, author of Plant-Thinking, and Through Vegetal Being (with Luce Irigaray).

5. The Philosopher's Plant (2014).

6. See Marder, Plant-Thinking, pp. 3-4, where he describes plants as 'wholly other and foreign to us'.

7. Plant-Thinking, p. 12, where Marder discusses the 'spatio-temporal' nature of plants.

8. Marder, Plant-Thinking, pp. 1-13. See especially the opening pages of this introduction, in which this manifesto is laid out with incisive flair.

9. See Homo Novus web site archive: http://www.homonovus.lv/eng/performances.php?s=lost-gardens, date accessed 10 March 2015.

10. See Homo Novus web site archive. 
11. Peter Sloterdijk (2005) 'Atmospheric Politics' in Making Things Public: Atmospheres of Democracy, pp. 944-51.

12. Abish, 'The English Garden Effect', p. 1.

\section{REFERENCES}

Abandoned Practices. http://abandonedpractices.org. Date accessed 1 June 2015. Abish, Walter. 1980. The English Garden Effect. In In the Future Perfect, 1-21. London: Faber.

Deleuze, Gilles, and Guattari, Felix. 2004. A Thousand Plateaus: Capitalism and Schizophrenia. Trans. Brian Massumi. London: Continuum.

Guattari, Félix. 2000. The Three Ecologies. Trans. Ian Pindar, and Paul Sutton. London/New Brunswick: Athlone.

Krauss, Rosalind. 1979. Sculpture in the Expanded Field. October 8: 30-44.

Marder, Michael. 2013. Plant-Thinking: A Philosophy of Vegetal Life. New York: Columbia University Press.

- 2014. The Philosopher's Plant. New York: Columbia University Press.

Nietzsche, Friedrich. 2017. The Will to Power. Trans. Michael A. Scarpitti, and R. Kevin Hill. London: Penguin.

Ophir, Adi. 2000. The Order of Evils. New York: Zone Books.

Read, Alan. 2008. Theatre, Intimacy \& Engagement: The Last Human Venue. New York: Palgrave.

Shiva, Vandana. 1988. Staying Alive: Women, Ecology and Survival in India. New Delhi: Kali for Women. http://gyanpedia.in/Portals/0/Toys\%20from\%20 Trash/Resources/books/stayingalive.pdf. Date accessed 10 Apr 2015.

- 1997. Biopiracy: The Plunder of Nature and Knowledge. Boston: Southern End Press.

Sloterdijk, Peter. 2005. Atmospheric Politics. In Making Things Public: Atmospheres of Democracy, ed. Bruno Latour and Peter Weibel, 944-951. Cambridge: MIT Press.

Stengers, Isabelle. 2007. Diderot's Egg. In Radical Philosophy, 144, July/August. http://roundtable.kein.org/sites/newtable.kein.org/files/MaterialismDiderot.pdf. Date accessed 10 Apr 2015.

Thoreau, Henry David. 1916. The Maine Woods. Boston: Houghton Mifflin.

Weiss, Allen. 1999. Unnatural Horizons: Paradox and Contradiction in Landscape Architecture. Princeton: Princeton Architectural Press. 
Open Access This chapter is licensed under the terms of the Creative Commons Attribution 4.0 International License (http://creativecommons.org/licenses/ by $/ 4.0 /$ ), which permits use, sharing, adaptation, distribution and reproduction in any medium or format, as long as you give appropriate credit to the original author(s) and the source, provide a link to the Creative Commons licence and indicate if changes were made.

The images or other third party material in this chapter are included in the chapter's Creative Commons licence, unless indicated otherwise in a credit line to the material. If material is not included in the chapter's Creative Commons licence and your intended use is not permitted by statutory regulation or exceeds the permitted use, you will need to obtain permission directly from the copyright holder.

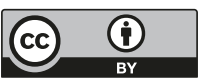

